\title{
A construção de um Brasil imaginado estética e ideologicamente
}

\author{
Bruno Lima*
}

\section{Resumo}

Mário de Andrade relembra, vinte anos após a Semana de Arte Moderna, o caráter de fundação de um espírito nacional ser atribuído ao modernismo, sem o qual a consciência da nacionalidade brasileira não teria se desenvolvido. A partir do pensamento de Benedict Anderson a respeito do conceito de nação e de consciência nacional, revisitamos alguns pontos nodais da obra andradina de modo a problematizar criticamente sua convicção da questão nacional ser tributária ao modernismo. Outro autor igualmente importante dentre os modernistas de primeira hora é Oswald de Andrade, que contribui com a tentativa de formação identitária do Brasil. O teor vanguardista do movimento de 22 é também colocado em xeque com o confronto entre o futurismo de Marinetti e sua absorção por Oswald, evidenciando os paradoxos modernistas nas suas nuances vanguardistas e nacionais. Ao nos aproximarmos da comemoração do centenário da Semana, levantamos questões críticas importantes acerca do modernismo, sem com isso pretender desmerecer a qualidade estético-literária do movimento.

Palavras-chave: Modernismo. Vanguarda. Nação. Consciência nacional. Literatura brasileira.

\footnotetext{
* Programa de Pós-Graduação da Faculdade Unyleya. Doutor em Estudos Literários (UERJ). Desenvolve pesquisas sobre o cânone, Machado de Assis e literatura contemporânea; publicou, dentre outros, os livros Bruxaria do início ao fim: o projeto filosófico-(meta)-ficcional de Machado de Assis (EDUERJ, 2021) e Eu: itinerário para a autoficção (7Letras, 2015). ORCID: https://orcid.org/my-orcid?orcid=0000-0001-9464-4293.
} 


\title{
The construction of an aesthetically and ideologically imagined Brazil
}

\begin{abstract}
Mário de Andrade recalls, twenty years after the Week of Modern Art, the founding character of a national spirit to be attributed to modernism, without which the awareness of Brazilian nationality would not have developed. Considering Benedict Anderson's thought about the concept of nation and national consciousness, we revisit some nodal points of Andrade's work to critically problematize his conviction on the national question to be stemming from modernism. Another equally important author among the early modernists is Oswald de Andrade, who contributes to the attempt to form Brazil's identity. The vanguardist content of the Brazilian modernist movement is also jeopardized with the confrontation between Marinetti's futurism and Oswald's absorption of it, emphasizing the modernist paradoxes in their avant-garde and national nuances. Close to the celebration of the centenary of the Week, we raise important critical questions about modernism, with no intention to disregard the movement's aesthetic-literary quality.
\end{abstract}

Keywords: Modernism. Vanguard. Nation. National consciousness. Brazilian literature.

Recebido em: 15/05/2021 // Aceito em: 18/12/2021. 
A poucos meses do centenário da inauguração da Semana de Arte Moderna, data que renova a estética literária e artística no Brasil, é importante revisar alguns pontos considerados norteadores daquele movimento, hoje canônico e revisto pelos mais importantes estudiosos do país. Não é fortuita a data para o evento que procurou redirecionar o espírito nacional, exatamente um século após a independência brasileira. $\mathrm{O}$ caráter iconoclasta do movimento modernista visava, portanto, dentre outros aspectos, repudiar a herança europeia deixada pelos colonizadores e fundar uma arte e uma literatura genuinamente brasileiras. Mário de Andrade, senão o principal, um dos mais influentes escritores modernistas, em conferência realizada vinte anos após a Semana, assim inicia o balanço que fizera do movimento:

Manifestado especialmente pela arte, mas manchando também com violência os costumes sociais e políticos, o movimento modernista foi o prenunciador, o preparador e por muitas partes o criador de um estado de espírito nacional. A transformação do mundo com o enfraquecimento gradativo dos grandes impérios, com a prática européia de novos ideais políticos, a rapidez dos transportes e mil e uma outras causas internacionais, bem como o desenvolvimento da consciência americana e brasileira, os progressos internos da técnica e da educação, impunham a criação de um espírito novo e exigiam a reverificação e mesmo a remodelação da Inteligência nacional. (ANDRADE, 1974, p.231).

Oexcertoacima ensejamaisquestionamentos doquecertezas, na contramão das verdades indeléveis repetidas à exaustão acerca do modernismo. Em primeiro lugar, o romantismo pretendera igualmente apartar o Brasil de Portugal e, assim, fundar uma nacionalidade brasileira. Podemos questionar, naturalmente, assim como o fizeram os modernistas, a estética empregada por 
José de Alencar na construção identitária do índio, que seria, na pena do escritor cearense, o primeiro brasileiro por excelência. A caracterização de Peri mais o assemelha à nobreza branca $\mathrm{e}$ europeia e menos o torna verossímil com a cultura indígena aqui existente antes da colonização - a leitura de A demanda do Santo Graal ou de qualquer outra novela de cavalaria reforça a idealização do índio próxima ao ideal aristocrático, religioso e social caro ao projeto de Alencar. Em segundo lugar, tornar-se paradoxal a autodenominação modernista de criador do espírito nacional uma vez que é graças também à estética fundada na Europa, além das "mil e uma outras causas internacionais", que suas ideias ganham fôlego. Sabemos que Oswald de Andrade, em viagem ao velho continente, travara contato com os manifestos futuristas de Marinetti e se apropria deles -mais à frente, discutiremos o Manifesto antropófago de Oswald. Do mesmo modo que o romantismo brasileiro se inicia, como rezam os manuais de historiografia literária, com Suspiros poéticos e saudades, de Gonçalves de Magalhães, escrito em Portugal, é o futurismo de Marinetti, escritor italiano mas que publica o primeiro manifesto em Paris, um moto-contínuo modernista - "Oswald de Andrade, numa viagem a Paris, [...] descobriu, deslumbrado, a sua própria terra."(PRADO, 2001, p.57). Ambas as escolas se pretendiam nacionais mas sem abdicar da influência europeia, muito embora os primeiros modernistas operassem em outra estética, diversa do academicismo criticado nos românticos. Em conferência realizada no Museu Nacional de Belas Artes, Eduardo Portella distingue em dois o movimento romântico e conclui que "podemos talvez afirmar que devemos fundamentalmente ao romantismo da cisão, ao romantismo modernizador, o encaminhamento moderno da literatura no 
Ocidente e no Brasil." (PORTELLA, 1981, p.29). Em outras palavras, não haveria modernismo não fosse o caminho aberto pelo romantismo, observação válida, a propósito, para todas as escolas literárias que pretendem sobrepujar a estética anterior e oferecer, assim, um novo direcionamento estético e estilístico para as artes e para a literatura.

Registramos que a preocupação com uma literatura nacional é historicamente recente. Dom Quixote, por exemplo, após toda a sorte de aventuras por que passou, termina o romance regressando à sua pátria, isto é, à sua aldeia. Naquele tempo, o conceito de nação inexistia e nada mais natural do que se sentir pátrio de sua terra natal, mesmo sendo esta apenas um lugarejo. Hoje, considera-se a obra cervantina espanhola, porém tal designação pouca ou nenhuma serventia possuía quando da publicação do livro fundador do romance como gênero. Para reforçar essa ideia, lembramos que Platão, ao escrever A república, designava uma cidade, não se referindo à Grécia como nação, ou seja, seria inimaginável "localizar a República de Platão em qualquer mapa, fictício ou real [...]” (ANDERSON, 1989, p.79); pensar em termos de nacionalidade constituiria anacronismo, portanto. Benedict Anderson dedica-se a pesquisar tanto nação quanto consciência nacional, o que os modernistas se vangloriavam de ter criado. O pesquisador estadunidense define nação como uma comunidade política imaginada de forma limitada e soberana. $\mathrm{O}$ limite se dá pelas fronteiras, e a soberania, pela independência. Uma nação, de acordo com Benedict Anderson, abrange uma quantidade de indivíduos com muitas coisas em comum, muito embora não se conheçam nem virão um dia a se conhecer, mas todos possuem a consciência de que se igualam justamente pela nacionalidade, ou melhor, pela consciência nacional. Apesar 
das diferenças sociais, políticas, econômicas etc., todos os indivíduos de uma mesma nação consideram-se pertencentes a ela, principalmente pelo poder que a língua e a literatura conferem a cada cidadão em particular. Seja no Acre, seja no Rio Grande do Sul, para citar os estados extremos do Brasil, há linguisticamente uma igualdade que aproxima acreanos e gaúchos como pertencentes a uma mesma nação. Porém, os moradores do Brasil se percebem distantes dos demais países lusófonos porque não comungam da mesma política. Isso se dá, entre outras razões, porque "pode-se perceber bem melhor por que essa transformação seria tão importante para o nascimento da comunidade imaginada da nação se considerarmos a estrutura básica de duas formas de imaginar que floresceram na Europa, no século XVIII: o romance e o jornal.” (ANDERSON, 1989, p.34). O romance tratará de assuntos pertencentes a apenas uma comunidade imaginada, ao passo que o jornal noticiará temas relevantes à soberania política de um único Estado, ou, no caso de notícias internacionais, os leitores terão ciência de que elas tratam de alhures. Lembremos que a reivindicação de nacionalidades literárias acompanha o próprio nascimento do conceito moderno de nação, uma vez que "talvez nada acelerasse mais essa busca, nem a tornasse mais frutífera, do que o capitalismo editorial, que tornou possível, a um número cada vez maior de pessoas, pensarem sobre si mesmas, e se relacionarem com outras, de maneira profundamente renovada." (ANDERSON, 1989, p.45). Nesse sentido, podemos avaliar como promissora a poética e a narrativa modernistas, mas não menos eficaz a romântica. Ambas as escolas utilizaram a contento os jornais e a literatura para a formação de uma identidade nacional. O Brasil oitocentista acompanhou seriadamente os romances em folhetim, assim 
como sua posterior publicação em livro; os modernistas de primeira hora, por seu turno, além das tiragens editoriais de suas obras, utilizaram a imprensa como forma de subsidiar seus ideais, haja vista a publicação dos manifestos, por exemplo, ocorrer nos jornais, maneira hábil e eficaz de alcançar um grande número de leitores. "Esses co-leitores, a que estavam ligados pela imprensa, formavam, em sua visível invisibilidade secular e peculiar, o embrião da comunidade nacionalmente imaginada." (ANDERSON, 1989, p.54).

A preocupação com uma literatura brasileira antecede os modernistas, não apenas em razão dos românticos terem se dedicado a ela, mas principalmente pelo fato de o Brasil ter sido colônia de Portugal por pouco mais de três séculos. Os manuais de história da literatura brasileira costumam iniciar o estudo de nossas letras com a publicação da carta de Pero Vaz de Caminha, com os sermões jesuítas e com o barroco, ainda que não fôssemos uma nação independente. E não poderia ser diferente, haja vista não sermos ainda uma nação constituída nem sequer haver tal conceito. Os modernistas irão, enfim, retomar tal questão e se autoproclamar os verdadeiros fundadores da consciência nacional brasileira.

A leitura de Macunaíma, de Mário de Andrade, obra-prima modernista, oferece, por um lado, tentativa exemplar de uma formação nacionalista temática e linguística, mas, por outro, apresenta as contradições típicas do modernismo. Sem a pretensão de esgotar o romance-rapsódia, anotamos a reformulação da gênese indianista proposta pelos românticos com uma linguagem o mais distante possível do vernáculo e da sintaxe portugueses, de modo a apresentar o que seria a língua brasileira, “o estandarte mais colorido dessa radicação à pátria" (ANDRADE, 1974, 
p.244). O próprio autor, na referida conferência que dera em 1942, queixa-se daqueles autores que escreviam "certinho", alusão aos romancistas de 30, pluralizando, assim, modernismos. A própria tríplice subdivisão em três momentos do modernismo complexifica caracterizá-lo como um todo coeso e com unidade estética, mas aqui nos concentraremos no início desse movimento de vanguarda, com ênfase em Mário e Oswald de Andrade. A utilização de uma "língua brasileira" em Macunaíma é feliz e atende bem aos interesses nacionais modernistas, uma vez que "o que o nacionalismo inventa é a língua impressa, não 'uma' determinada língua por si só [...]” (ANDERSON, 1989, p.146, grifo do autor). Desse modo, as reclamações de Mário contra a discrepância do português falado e escrito no Brasil são muito coerentes com seu projeto literário, cultural e político, pois tornava-se imprescindível que adotássemos na literatura a fala coloquial do brasileiro. Porém, para um país continental como o Brasil, com tantas e diversificadas influências linguísticas, a exigência de uma unificação idiomática parece-nos ingenuidade, senão um limite impossível de se resolver.

O Brasil é um país multilíngue, onde são faladas línguas trazidas por imigrantes, variedades locais do português brasileiro, línguas de sinais, falares de comunidades de afrodescendentes e línguas indígenas. Estima-se que, no Brasil, sobrevivem mais de 150 línguas indígenas. Esse número parece grande? Não é. Comparado com a paisagem de 500 anos atrás, é um número pequeno. Considera-se que, no decorrer do tempo colonial, foram apagadas pelo menos $80 \%$ das línguas de povos nativos. Além disso, todas as línguas que sobreviveram são ameaçadas até hoje. Algumas estão à beira do desaparecimento. (BALYKOVA, 2021, p.7-8). 
A formação multirracial brasileira costuma indicar três raças responsáveis pela miscigenação de nosso povo: brancos, índios e negros. Contudo, essa tríplice divisão parece esquecerse de que, dentre os indígenas, havia quantidade ímpar de comunidades diferentes linguisticamente, do mesmo modo que os africanos escravizados provinham de localidades distintas idiomaticamente; no segundo decênio do século passado, já com o fim da escravidão, somam-se aos brancos portugueses outros tantos advindos de várias nacionalidades e culturas que vieram para suprir a mão de obra escrava. Desse modo, é impossível negar a contribuição de outros costumes e línguas para a formação do país. A pluralidade linguística no Brasil é inequívoca, e restringir todo o curso idiomático a uma única língua constitui erro tanto dos românticos quanto dos modernistas. Nessa direção, são importantes os estudos culturais e pós-coloniais que oferecem novas, importantes e atuais ressignificações para essas questões metodológicas. É imprescindível uma reflexão sobre questões da etnicidade para melhor compreender a literatura produzida nas Américas, como tem sido cada vez mais comum nos estudos literários e comparatistas. A esse respeito:

[...] a produção crítica sobre literatura no Brasil ainda tem um recorte nacional muito forte, no qual se prioriza a literatura brasileira, embora novos recortes já comecem a se fazer notar, o que me parece bastante promissor, pois a clausura do/no nacional tem impedido a compreensão de que movimentos e tendências surgidos em um país ou área linguística têm correlação com outros muito mais amplos que atingem outras regiões da América e mais particularmente da América Latina. (FIGUEIREDO, 2010, p. 19).

Para uma leitura analítica das literaturas americanas, incluindo a brasileira, naturalmente, é interessante a abordagem 
dos estudos pós-coloniais, uma vez que há, no novo mundo, singularidades que necessitam ser mais bem exploradas. Interessa observar, como bem sinaliza Eurídice Figueiredo (2010), que o termo "étnico" diz respeito ao que não é branco, ao Outro europeu, ou seja, designa, para nosso interesse presente, os negros escravizados e os povos originários das Américas, que, para os românticos e modernistas, era um ponto central na busca da constituição da nacionalidade brasileira. Nessa direção podemos situar a composição do romance-rapsódia andradino.

A reivindicação de Mário de Andrade de se falar brasileiro ignora a impossibilidade de conjugar para uma mesma língua nacional as centenas de idiomas que existiam antes dos portugueses aqui aportarem e restringe ao português o idioma europeu legado a nós, sem as devidas contribuições dos demais imigrantes. Nessa direção, a "carta pras icamiabas", escrita por Macunaíma, revela "ignorância" da riqueza linguística ainda hoje existente no Brasil.

Além disso, por mais que seja bem-sucedido, esteticamente, em desviar a norma culta do falar "certinho" caro aos filólogos, de acordo com o próprio herói sem caráter, há a preocupação em explicar para as icamiabas o que é São Paulo - com certa dose de ironia e crítica, decerto, mas por que singularizar a cidade paulistana, berço da "única gente útil do país"? (ANDRADE, 1992, p.65). O próprio autor afirma que o modernismo só poderia nascer em São Paulo, mas inegavelmente alastrouse por todo território nacional, como ele mesmo pretendia, apesar da "percepção utópica e crítica do próprio tempo e da própria cidade, transformada em paradigma para todo o Brasil.”(FABRIS, 1994, p.25). A abrangência territorial do movimento modernista, portanto, não deve ser espacialmente 
restrita a São Paulo. Já mencionamos a crítica feita por Mário à Geração de 30, cujas obras enfatizam o nordeste brasileiro e as relações de poder dos donos das terras, romances bastante diversos daqueles experimentais de Oswald de Andrade. A própria construção de um ideário nacional é singularizada de certo modo pelos modernistas mineiros, como escreve Martins de Almeida no editorial de A Revista: "Procuramos todos os esforços para construir o Brasil dentro do Brasil ou, se possível, Minas dentro de Minas." (ALMEIDA, 1925 apud BOMENY, 1994, p.77).A construção literária que dê cabo da totalidade brasileira esbarra na necessidade premente de alicerçar a própria localidade de onde se escreve, como no caso dos modernistas mineiros e da passagem da carta escrita por Macunaíma, para ficarmos apenas em dois exemplos. Ademais, tornar una uma nação com tamanha diversidade cultural e com heranças várias, indica antes empobrecimento nacional, no sentido justamente de se abdicar de importantes heranças distintas e restringir nossa inerente diversidade cultural a um único tópos.

Os românticos indianistas pretenderam expulsar brancos e negros da gênese brasileira, conferindo apenas ao índio o crédito por nossa formação; os modernistas, na esteira nacionalista de Mário, somaram os negros e os brancos, porém, ao criticar a sintaxe e a gramática lusitanas, estavam a negar uma das mais potentes heranças deixadas para o Brasil: a língua. Para Benedict Anderson, "a diversidade fatal das línguas humanas criou a possibilidade de uma nova forma de comunidade imaginada que, em sua morfologia básica, prepara o cenário da nação moderna." (ANDERSON, 1989, p.56). Excluir a língua portuguesa do rol de constituintes da cultura brasileira parecenos mais empobrecer o país do que enriquecê-lo. Ademais, a 
subversão sintática e ortográfica presente no romance-rapsódia marioandradino não constitui outra língua, apenas procura registrar um falar brasileiro mais próximo da coloquialidade de modo a reforçar a política nacional modernista, já que, "no seu próprio Macunaíma, também não se encontra essa 'língua brasileira' de consenso comum, senão, antes, um idioma artificial, compósito, de manipulação personalíssima." (CAMPOS, 2001, p.46).

Outro aspecto a se considerar diz respeito à crítica de plágio em Macunaíma sofrida por Mário de Andrade, o que enseja a "confissão" do autor ao afirmar: "Copiei, sim, meu querido defensor. O que me espanta e acho sublime de bondade, é os maldizentes se esquecerem de tudo quanto sabem, restringindo a minha cópia a Koch-Grünberg, quando copiei todos." (ANDRADE, 1931 apud SOUZA, 1999, p.164). Ele se justifica alegando que necessitava dar cor nacional a Macunaíma, retirando-o apenas do extremo-norte, porém causa surpresa o plágio, "difícil questão relativa à ausência de caráter do brasileiro" (SOUZA, 1999, p.94), ser feito da obra de um naturalista germânico. É paradoxal a necessidade de se copiar do estrangeiro o que viria a ser símbolo da nacionalidade brasileira. Eneida Maria de Souza oferece uma saída para esse impasse, ao afirmar o ponto nevrálgico do brasileiro, "perdido entre o encontro mortal da civilização europeia e igualmente vítima da sedução da Uiara, versão da Iracema de José de Alencar, símbolo, portanto, da nacionalidade." (SOUZA, 1999, p. 94). No entanto, fica a indagação: que Brasil imaginado Mário de Andrade buscava construir, no sentido de obliterar contribuições de várias localidades do país, com suas cultura e característica, e oferecer uma narrativa folclórica e mágica, sem respaldo verossímil para muitos brasileiros? Por que razão escolher o extremo-norte como berço de todo o Brasil, em espécie de metonímia? 
Oswald de Andrade é outro nome importante do modernismo e merece algumas breves considerações acerca do problema ao qual nos dedicamos. Poeta, prosador, dramaturgo e ensaísta, é de suma relevância para o movimento de vanguarda cujo marco é a Semana de Arte Moderna. Não apenas seus manifestos, mas sobretudo sua poesia, seus romances e suas peças merecem e devem ser lidos e discutidos à luz da ruptura estética operada pelo modernismo. Do mesmo modo que Mário, a literatura nacional era uma questão decisiva para Oswald. O Manifesto da poesia pau-brasil é exemplar da necessidade de se firmar uma tradição literária brasileira desatrelada da de Portugal e, por extensão, da de toda Europa. Todavia, como vimos, o contato com o futurismo é de relevância fundamental para se pensar a obra de Oswald e o próprio modernismo. Para ele, "o trabalho da geração futurista foi ciclópico. Acertar o relógio império da literatura nacional. Realizada essa etapa, o problema é outro. Ser regional e puro em sua época." (ANDRADE, 1992, p.330).Pensamos ser procedente uma leitura crítica da formulação acima. A busca por uma literatura nacional merece ser louvada após nossos cem anos de independência política, e carregar nossas letras com o que possuíamos de mais original seria um feito considerável, não apenas por apresentar um Brasil "desconhecido", mas igualmente por torná-lo esteticamente original, ou melhor, atual, distinção feita com maestria por Mário de Andrade. A produção imperial deveria ser corrigida sob os ponteiros de um novo tempo, moderno e em conformidade com as modificações sociais do século XX. Contudo, a "pureza" dessa literatura fica sub judice, uma vez que é impossível eliminar os vestígios de uma relação intrínseca e interdependente entre dominadores e dominados seguiremos doravante nossa argumentação em discordância da 
análise de Haroldo de Campos (2001), que reclama, inclusive, de Manuel Bandeira, que não chancelou a poesia oswaldiana, embora, aqui, não pretendamos desqualificá-la, apenas oferecer outra perspectiva acerca de seus manifestos. Por mais que se queira edificar obras genuinamente brasileiras, sem diálogo algum com o que fora escrito até então, é uma tarefa demasiadamente ambiciosa senão impossível, como já demonstramos. Convém lembrar que nomes como Manuel Bandeira e Mário de Andrade, antes da Semana de Arte Moderna, escreviam suas poesias com a rubrica de outra estética. Independentemente de Mário ter renegado sua produção parnasiana, a literatura é também intertextual, ou seja, é viável, saudável e explícito o diálogo com outras obras de outras nacionalidades, eliminando, assim, o desejo de algo puro. Com esse manifesto, "recuperaram-se fontes legítimas da cultura brasileira, que recebem o influxo das tendências vanguardistas universais, tais como a fragmentação proposta pelo Simbolismo, mediante a qual o poema se libera duma estruturação dominada pela logicidade. E aí lembramos a experiência renovadora de Mallarmé.” (HELENA, 1983, p.71). Lúcia Helena aponta com argúcia o dialogismo com as tendências modernistas europeias, às quais os escritores de 1922 se filiam, bem como a aproximação com o poeta francês, evidenciando uma exegese intertextual salutar.

Marinetti, influência de Oswald, pretende que o futurismo, como o nome indica, apresente uma arte que exalte a vida moderna, com o culto da máquina e da velocidade, e, por essa razão, destruindo o passado e os meios tradicionais da expressão, como a sintaxe, por exemplo. No manifesto do Futurismo, ele escreve: "Nós estamos sobre o peremptório extremo dos séculos!... Para que olhar para trás, no momento em que é preciso arrombar as 
misteriosas portas do impossível? O Tempo e o Espaço morreram ontem. Nós vivemos já no absoluto, já que nós criamos a eterna velocidade onipresente." (MARINETTI, 1992, p.92). Com base nessa premissa, qual a razão modernista de olhar para o passado para recriá-lo nacionalmente? Como reza a cartilha futurista, nenhuma importância teria o fato de termos "eruditado" tudo e esquecido o gavião de penacho, alusão de Oswald à subtração das riquezas brasileiras. Para ele, mais relevante seria olharmos para nosso carnaval, nossa riqueza vegetal, nossa culinária, nossas favelas, afinal, "a poesia reside nos fatos." (ANDRADE, 1992, p.326). Não é gratuita a denominação de Pau-Brasil para a nossa poesia, já que fora uma árvore muito cobiçada pelos portugueses e quase levada à extinção. Fica clara no manifesto em análise a necessidade de privilegiar nossa origem, afinal, o nome do país advém dessa árvore. Uma hipótese possível para esse olhar retrospectivo reside no "caráter incipiente de nosso desenvolvimento tecnológico e científico, que levava o artista a introjetar essa problemática fundamental na constituição do 'Real moderno', antes de vivê-la objetivamente.' (FABRIS, 1994, p.15). Apesar dos avanços do início do século XX, o Brasil ainda era um país essencialmente agrário cuja produção fabril caminhava a passos lentos. Evidentemente a modernidade chegara e era flagrante, pois já havíamos vivido a belle époque, arranha-céus e avenidas modificavam a geografia dos grandes centros urbanos etc.; todavia estávamos atrasados se comparados com a Europa e os Estados Unidos. A própria Geração de 30 evidencia o gradual declínio dos senhores de engenho diante da ainda nascente industrialização. A esse respeito Ronaldo Brito escreve: 
Paradoxal modernidade a de projetar para o futuro o que tentava resgatar do passado. Enquanto as vanguardas européias se empenhavam em dissolver identidades e derrubar os ícones da tradição, a vanguarda brasileira se esforçava para assumir as condições locais, caracterizálas, positivá-las, enfim. Este era o nosso "Ser" moderno. (BRITO, 1994 apud FABRIS, 1994, p.15).

Nossos modernistas caminhavam, nesse sentido, na contramão das vanguardas europeias, conciliando e misturando diversos elementos em vez de se centrarem no debate entre uma visão construtiva e um discurso subjetivo. A própria temática moderna não é exclusiva dos escritores do decênio de 1920 do século passado, haja vista os chamados pré-modernistas tratarem dessa questão em suas obras, como aponta Annateresa Fabris. Porém o epíteto "vanguardista" é bem qualificativo dos jovens iconoclastas capitaneados por Mário e Oswald de Andrade, no sentido de que questionavam a arte tanto em sua função específica quanto ideologicamente. A revisão crítica delineada aqui não desqualifica o êxito na transformação estética da literatura brasileira, seja na ruptura com os parnasianos, na desestrutura sintática, seja nos romances experimentais, bastante diversos do que se escrevia até então no Brasil. Contudo, se considerarmos o futurismo como norte, a arte moderna brasileira é antes de tudo local, aquém das propostas europeias. O Brasil sempre esteve atrasado, por assim dizer, com relação às correntes estéticas de além-mar, importando com algum déficit temporal o que era originalmente proposto pelos escritores europeus. " $\mathrm{O}$ surpreendente nesse quadro de referências é que, apesar disso, os modernistas consigam estruturar uma ação de vanguarda, vazada no exemplo futurista, do qual se aceita a plataforma ativista, mas não a proposta estético-artística, radical demais 
para o grupo de São Paulo." (FABRIS, 1994, p.21). Oswald pretende, portanto, substituir a poesia de importação por uma de exportação, como a define no Manifesto antropófago. Para ele, "Só me interessa o que não é meu. Lei do homem. Lei do antropófago." (ANDRADE, 1992, p.353). A labuta árdua em edificar uma literatura de fato nacional parece contraditória com a afirmativa acima. De onde proviria o interesse pelo alheio? Por que apenas com a absorção do "que não é meu” é possível devolver algo realmente brasileiro? Seria a Revolução Caraíba realmente maior do que a Revolução Francesa?

A crítica de Aracy Amaral, a respeito de Paulicéia Desvairada, mas que serve igualmente à formulação antropofágica de Oswald, questiona "o desejo colonizado de que os modernistas fossem os porta-vozes da França na América do Sul." (AMARAL, 1994, p.92).Pode-se inferir que ocorre uma substituição de cânone: enquanto a Academia, inimiga dos modernistas, baseava-se no referencial neoclássico, os modernistas primavam pelo pós-cubismo nas artes plásticas e expandindo-se também para a literatura, conforme analisa Carlos Zilio (1994). Inevitavelmente eles esbarravam na ausência de um escopo filosófico-literário nacional capaz de alicerçar as ideias que almejavam colocar em prática para a sustentação do projeto modernista. Não se trata de uma limitação daquele movimento, mas algo inerente à nossa própria história, refém da cultura europeia que formou a Inteligência nacional ao sobrepujar as contribuições indígenas e africanas. Luiz Costa Lima (1968) é feliz ao situar historicamente o problema de uma literatura brasileira refém dos modelos europeus. Segundo ele, até a República Velha seria impossível aos nossos escritores fugirem de certos limites impostos, principalmente utilizando a língua de 
maneira não convencional, por sermos ainda fundamentalmente uma sociedade de base rural. Sob esse aspecto, a crítica dos modernistas de primeira hora aos românticos e parnasianos seria descabida, uma vez que os escritores dessas escolas, consideradas ultrapassadas, não poderiam produzir algo diverso até então; em contrapartida os "jovens aristocráticos" da Semana mereceriam o louvor da desestruturação linguística e o desejo de formular uma língua brasileira. Porém, ainda merece investigação o desejo antropofágico pelo alheio.

Lúcia Helena oferece um texto bastante esclarecedor e abrangente sobre uma literatura antropofágica. A pesquisadora parte do manifesto de Oswald para, assim como fizeram os modernistas, lançar um olhar crítico retrospectivo, remontando a antropofagia a Gregório de Matos. Como já discutimos, ela reconhece a base europeia de nosso modernismo, que, dialeticamente, absorve o que vem de fora para devolver uma realidade de fato brasileira:

Sob a denominação de antropofagia, Oswald sintetizava um projeto estético-cultural: a busca de deglutir as influências poético-ideológicas européias, incorporando-as criticamente às matrizes nacionais, através da "paródia", para, deste modo, construir um discurso literário de dicção autonomamente brasileira, imune aos sectarismos e ufanismos. (HELENA, 1983, p.23, grifo da autora).

Exemplo parodístico encontramos no início do próprio Manifesto antropófago: "Tupy or not tupy, that is the question." (ANDRADE, 1992, p.353). Parodiando Skakespeare, há novamente a questão da ancestralidade brasileira colocada em relevo, fazendo referência ao idioma indígena. Ao subverter a célebre expressão de Hamlet, Oswald de Andrade, ironicamente, 
reafirma a necessidade de aceitarmos e firmarmos nossa descendência. Benedict Anderson afirma que, curiosamente, as nações americanas que se tornaram independentes não nutrem ódio pelas ex-metrópoles, mas se não há ódio no caso modernista, é flagrante, pelo menos, uma forte inclinação em apagar os anos de colonização e em afirmar a existência primeira dos povos que habitavam o que viria a ser o Brasil. No entanto, mais uma vez a história é em parte ignorada, ou melhor, é imposta uma limitação idiomática e dos povos nativos do país, pois:

[...] em primeiro lugar, a palavra "índio", no singular, apaga a existência de muitos povos distintos. Em segundo lugar, "tupi" apaga a existência de muitas línguas diferentes. Tupi é o nome não de uma única língua, mas de uma grande família que abriga dezenas de línguas. Uma delas é o tupinambá (ou tupi antigo), que está ressurgindo hoje. (BALYKOVA, 2021, p.7).

Independentemente do equívoco, não apenas de Mário ou Oswald, mas extensivo à maioria da população brasileira de restringir o idioma tupi a uma única língua falada por todos os povos originários do Brasil, é clara a intenção nacional por trás da paródia citada - lembremos que Policarpo Quaresma exigia igualmente que seu país adotasse o tupi como língua nacional, ou seja, é patente a necessidade literária de retroceder às nossas origens, como procuramos demonstrar aqui. $\mathrm{O}$ mesmo problema ocorre com os negros, comumente considerados todos provenientes de uma mesma localidade linguística e cultural. A miscigenação que resultou em nosso povo o torna plural, impossibilitando uma matriz capaz de originar uma ancestralidade regional e "pura", como advogava Oswald de Andrade. 
O próprio Manifesto antropófago pode ser compreendido de modo a recuperar nossas letras desde o controverso Gregório de Matos, "esse 'antropófago' de Salvador [que] foi o autor de nossa primeira linhagem de 'macunaímas', os heróis sem nenhum caráter, caldeados na paródia das raças, das vozes múltiplas, das ideologias miscigenadas [...]" (HELENA, 1983, p.26). Segundo Lúcia Helena, há em comum, entre Oswald e Gregório, uma vertente antropofágica e carnavalizante em suas respectivas poesias. Ao analisar a obra do poeta barroco, a ensaísta percebe a verve antropofágica no sentido de que ele substitui ironicamente a verdade do colonizador pela sua verdade particular, seja tematicamente, seja por meio de elementos semânticos e sonoros. Porém, como salienta Mário de Andrade, a individualidade em Gregório não constitui ipso facto uma reivindicação nacional. Ainda de acordo com Lúcia Helena, o autor de Macunaíma, em seu romance-rapsódia, recupera a erotização do nacional presente desde o Boca do Inferno. A possíveis questionamentos que a leitura extemporânea da antropofagia possa suscitar, a ensaísta esclarece que há duas interpretações plausíveis para o manifesto proposto por Oswald de Andrade: "a primeira focaliza-a como ethos da cultura brasileira, que se manifesta desde a literatura do período colonial (em especial em Gregório de Matos) aos nossos dias." (HELENA, 1983, p.91). A partir dessa formulação, concluímos que a ideia de apropriação contida no manifesto em análise é algo presente, em maior ou menor grau, na literatura brasileira desde sempre. A segunda interpretação reside no modernismo strictu senso.

Vejamos, portanto, outro exemplo não contemplado por Lúcia Helena e que remonta ao século XIX tão criticado pelos modernistas. Machado de Assis, considerado nosso maior nome 
literário, é alvo das críticas de Mário de Andrade, que, apesar disso, reconhece sua qualidade como escritor. A ruptura estética entre Iaiá Garcia e Memórias póstumas de Brás Cubas é conhecida e amplamente discutida pelos machadianos e, por essa razão, limitaremos nossa observação a um breve aspecto que dialoga com o manifesto de Oswald.

João Cezar de Castro Rocha oferece uma hipótese bastante interessante que visa a elucidar a mencionada ruptura estética divisora em duas fases a obra de Machado. Para o pesquisador, o bruxo do Cosme Velho possuía consciência de que jamais conseguiria ascender como escritor lusófono reconhecido internacionalmente por duas razões: i) duplamente periférico, seja linguisticamente, por estar à margem das literaturas anglófonas e francófonas, seja geograficamente, por residir fora do centro europeu, necessitava de uma guinada estética no que produzira em seus quatro primeiros romances; ii) sem uma substancial alteração em seu estilo, jamais conseguiria ombrear com Eça de Queirós, cujos sucessos de $\mathbf{O}$ crime do padre Amaro e de $\mathbf{O}$ primo Basílio, ambos realistas, elevavam o autor português como grande nome literário em nosso idioma. Machado, avesso ao realismo, como escrevera na conhecida polêmica com Eça, decide emular autores portugueses anteriores ao realista e então recupera a literatura de Almeida Garret. É flagrante, na obra machadiana, o dialogismo explícito com grandes nomes da literatura universal, sendo Shakespeare um dos mais recorrentes, a julgar pela emulação contida em Dom Casmurro, por exemplo. De modo a não nos determos mais que o necessário na obra do bruxo e na hipótese de João Cezar de Castro Rocha, anotamos que a absorção de obras estrangeiras ocorre em Machado de Assis de modo a ressignificá-las e então 
apresentar obras-primas da literatura brasileira. O romance que aborda o ciúme de Bento Santiago não é o único que se vale desse subterfúgio, presente nas memórias de um defunto-autor, na análise de João Cezar. Segundo ele, a poética da emulação aparece em Machado porque, "ao conceber a originalidade como inventio, o autor se metamorfoseia em leitor agudo da tradição, através de reciclagens e ruminações, que levam à celebração das 'filiações', no espírito oswaldiano, pois elas asseguram o ingresso no circuito da tradição." (ROCHA, 2013, p.207). Sabemos que a tradição, contudo, é criticada pelos modernistas, em consonância com o movimento de vanguarda destruidor surgido a partir da Semana, apesar de que, no segundo momento modernista, a tradição se faz presente, como aponta Silviano Santiago (2002). Mas o que importa, aqui, é registrar que a absorção do estrangeiro como matéria para se devolver uma realidade brasileira antecedia os modernistas, guardadas, evidentemente, as devidas ressalvas.

Machado de Assis, com toda a diversidade textual e tipológica de sua pena, também escreveu um ensaio sobre a questão do nacional que nos interessa sobremaneira. Em Instinto de Nacionalidade, ele é taxativo:

Não há dúvida que uma literatura, sobretudo uma literatura nascente, deve principalmente alimentarse dos assuntos que lhe oferece a sua região, mas não estabeleçamos doutrinas tão absolutas que a empobreçam. $\mathrm{O}$ que deve exigir do escritor, antes de tudo, é certo sentimento íntimo, que o torne homem do seu tempo e do seu país, ainda quando trate de assuntos remotos no tempo e no espaço. Um notável crítico da França, analisando há tempos escritor escocês, Masson, com muito acerto dizia que do mesmo modo que se podia ser bretão sem falar sempre do tojo, assim Masson era bem escocês, sem dizer palavra do cardo, 
e explicava o dito acrescentando que havia nele um scotticismo interior, diverso e melhor do que se fora apenas superficial. (ASSIS, 1938, p.139-40).

O antológico ensaio de Machado é rico no que se refere à literatura nacional, sobretudo se pensado quando da data de sua publicação, 1873, pois a Europa na "primeira metade do século XIX assistia ao borbulhar dos movimentos nacionalistas de natureza local [...]" (ANDERSON, 1989, p.148). Mais que dar cor local literariamente às obras, cabe ao escritor a manutenção de um sentimento íntimo com sua terra. Desse modo, mesmo que opte em situar sua narrativa fora do país, ela permanecerá nacional em virtude justamente desse sentimento nutrido, por seu autor, pelo país de berço, capaz de olhar e escrever o estrangeiro com uma ótica nacional. No caso de Machado, podemos fazer coro com os modernistas e alegar que o bruxo foge de uma língua brasileira, preso ao academicismo e a uma gramática lusitana, mas, recuperando Costa Lima, não era possível até então escrever de outro modo. Não nos esqueçamos que Macunaíma foi "copiado" em parte da obra de um naturalista germânico, mas nem por isso deixa de ser uma obra-prima da literatura brasileira, oferecendo aos leitores um Brasil a servir de modelo, cujo herói é, ao menos na alegoria proposta por Mário, a simbologia do brasileiro.

Gregório de Matos, na interpretação de Lúcia Helena - que estende a antropofagia também a Augusto dos Anjos, do qual não nos ocuparemos -, e Machado de Assis, na hermenêutica de João Cezar de Castro Rocha, são exemplares da absorção do "que não é meu" muito antes da publicação do Manifesto antropófago. Não pretendemos afirmar que a antropofagia literária é anterior ao modernismo, mas tão somente evidenciar aspectos em 
comum entre esses autores, embora com propósitos e estéticas divergentes. Se de fato "[n] unca fomos catequizados. Fizemos foi Carnaval [...]" (ANDRADE, 1992, p.356), a aproximação com o aspecto carnavalizante e irônico de Gregório de Matos proposto pela ensaísta é justa, pertinente e verossímil. De igual modo, Machado já "comia" e "deglutia" Garret, escritor português, porque, nas palavras oswaldianas, "somos fortes e vingativos como o Jabuti [...]" (ANDRADE, 1992, p.357), muito embora, repetimos, ideologicamente distam as intenções machadianas e modernistas.

O modernismo é um movimento vanguardista rico e complexo, cujas nuances suscitam discussões várias. Sabemos ser impossível falar de modernismo, no singular, haja vista a divisão em três momentos distintos, que obedece mais a necessidade didática de se compreender um período da historiografia literária no Brasil em uniformidade, mas cuja riqueza de autores diversos com suas particularidades é quase inesgotável. Contudo:

[o] elo comum a Mário e Oswald seria, sem dúvida alguma, a consciência de que a oposição aos cânones da poesia anterior ao Modernismo é um compromisso com a evolução da forma artística, que está em contínuo diálogo com o real, não para oferecernos sua reduplicação, mas para propor-nos novas e indispensáveis aberturas. (HELENA, 1983, p.87).

São esses dois autores do modernismo de primeira hora, a nosso ver, os responsáveis mais atuantes para a consolidação do projeto estético-cultural que se apresentava, cujo um dos objetivos era o de buscar nossas verdadeiras raízes e, simultaneamente, questionar a produção literária e artística do período colonial. Obras de valor foram legadas para a posteridade, cujas influências eclodem em outros momentos importantes das artes no Brasil, 
como a Tropicália e o Cinema Novo. Todavia, não podemos ignorar as contradições a que se lançava a dupla em análise, seja por buscar uma nacionalidade pretérita impossível de se cristalizar, seja pelo viés paradoxal que essa tentativa explicitava (em um movimento que se pretendia de vanguarda, alicerçado pelas vanguardas europeias, que não ecoavam aqui, em função do atraso local) e cujas proposições de ideias novas retrocediam ao passado de modo a recriá-lo.

Porém, a admissão de êxito na recriação de uma nacionalidade genuinamente brasileira, divergente daquela pretendida pelos românticos, por exemplo, enseja a seguinte questão: que comunidade imaginada corresponderia ao ideário comum a todos os brasileiros, de norte a sul do país, sem restrições e subtrações linguísticas e culturais? Acrescenta-se o questionamento sobre ser viável unir as diversas culturas que colaboraram para a consolidação multirracial e multilinguística do Brasil sem prejuízo de nenhuma delas, admitindo, antes de negar, a contribuição de todas para a pluralidade de nosso povo. A miscigenação nos formou, tornando-nos uma miscelânea singular, porque plural. A nacionalidade construída ou reivindicada pelos modernistas é antes uma idealização imaginada como adequada para o Brasil, cujos traços são remodelados sob preceitos estéticos e ideológicos. Uma das proposições diz respeito à "pureza" identitária do país, soberano e independente de quaisquer vestígios de outras nações, mas não podemos nos esquecer que:

[...] as Memórias sentimentais de João Miramar e Serafim Ponte Grande se desenrolam em tôrno do deslocamento de personagens entre o Novo e o Velho Mundo, exprimindo a posição do homem americano, que êle[Oswald] viveu com intensidade, ao adquirir 
consciência da revisão de valores tradicionais em face das novas experiências de arte e de vida. (CANDIDO, 1959, p.89).

Fica claro, inclusive na ficção de Oswald, o intercâmbio entre Brasil e Europa, sem o qual o modernismo inexistiria. $\mathrm{O}$ próprio Candido alude para o fato de que o sobrenome Miramar caracteriza a necessidade de contemplação do "mar dos embarques", maneira de aproximá-lo do continente europeu.

Indubitavelmente, o modernismo é de suma importância para a literatura e cultura brasileiras, com obras de valor incomensurável para as nossas letras. Não é sem razão sua canonização, mas acreditamos ser procedente uma revisão crítica de alguns pontos nodais daquele movimento em vez de cair na armadilha de laureações panegíricas.

\section{Referências}

AMARAL, Aracy. A imagem da cidade moderna: o cenário e seu avesso. In: FABRIS, Annateresa (org.). Modernidade e modernismo no Brasil. Campinas: Mercado de Letras, 1994. p.89-95.

ANDERSON, Benedict. Nação e consciência nacional. Tradução de Lólio Lourenço de Oliveira. São Paulo: Ática, 1989. ANDRADE, Mário de. Macunaíma o heroi sem nenhum caráter. 28. ed. Belo Horizonte: Villa Rica Editoras Reunidas Ltda., 1992.

ANDRADE, Mário de. O movimento modernista. In: ANDRADE, Mário de. Aspectos da literatura brasileira. 5. ed. São Paulo: Martins, 1974. p.231-255. 
ANDRADE, Oswald. Pau-Brasil. 7. ed. São Paulo: Globo, 2001.

ANDRADE, Oswald. Manifesto da poesia pau-brasil.In: TELES, Gilberto Mendonça. Vanguarda europeia e modernismo brasileiro. 11. ed. Petrópolis: Vozes, 1992. p.326-331.

ANDRADE, Oswald. Manifesto antropófago. In: TELES, Gilberto Mendonça. Vanguarda europeia e modernismo brasileiro. 11. ed. Petrópolis: Vozes, 1992. p.353-360.

AVILA, Affonso. O poeta e a consciência crítica. Petrópolis: Vozes, 1969.

BALYKOVA, Kristina (org.). Índio não fala só tupi: uma viagem pelas línguas dos povos originários no Brasil. Rio de Janeiro: 7 Letras, 2021.

BOMENY, Helena. Guardiães da razão: modernistas mineiros. Rio de Janeiro: EdUFRJ; Tempo Brasileiro, 1994.

BOSI, Alfredo. Pré-modernismo e modernismo. In: BOSI, Alfredo. História concisa da literatura brasileira. São Paulo: Cultrix, 1994. p.301-379.

CAMPOS, Haroldo. O sequestro do barroco na formação da literatura brasileira: o caso Gregório de Matos. São Paulo: Iluminuras, 2011.

CAMPOS, Haroldo de. Uma poética da radicalidade. In: ANDRADE, Oswald. Pau-Brasil. 7. ed. São Paulo: Globo, 2001. p.7-53.

CANDIDO, Antonio. Introdução. In: CANDIDO, Antonio. Formação da literatura brasileira. 6. ed. Belo Horizonte: Itatiaia, 1981. p.21-39.

CANDIDO, Antonio. Lembrança de Mário de Andrade; Oswald viajante. In: CANDIDO, Antonio. O observador literário. São Paulo: Conselho Estadual de Cultura, 1959. p. 83-88; p. 89-93. 
CANDIDO, Antonio. Digressão sentimental sobre Oswald de Andrade. In: CANDIDO, Antonio. Vários escritos. São Paulo: Livraria Duas Cidades, 1970. p. 57-87.

COSTA LIMA, Luiz. Lira e antilira. Rio de Janeiro: Civilização Brasileira, 1968.

FABRIS, Annateresa. Modernidade e vanguarda: o caso brasileiro. In: FABRIS, Annateresa (org.). Modernidade e modernismo no Brasil. Campinas: Mercado de Letras, 1994. p.9-25.

FIGUEIREDO, Eurídice. Representações da etnicidade: perspectivas interamericanas de literatura e cultura. Rio de Janeiro: 7 Letras, 2010.

HELENA, Lúcia. Uma literatura antropofágica. 2. ed. Fortaleza: Edições UFC, 1983.

ASSIS, Joaquim Maria Machado de. Literatura brasileira: instinto de nacionalidade. In: ASSIS, Joaquim Maria Machado de. Critica litteraria. Rio de Janeiro; São Paulo; Porto Alegre: W. M. Jackson Inc. Editores, 1938. p.133-154.

MARINETTI, Filippo Tommaso. Manifesto do Futurismo. In: TELES, Gilberto Mendonça. Vanguarda europeia e modernismo brasileiro. 11. ed. Petrópolis: Vozes, 1992. p.91-2. MORAES, Eduardo Jardim de. A estética de Mário de Andrade. In: FABRIS, Annateresa (org.). Modernidade e modernismo no Brasil. Campinas: Mercado de Letras, 1994. p.133-144.

PORTELLA, Eduardo. Romantismo e modernidade. In: PORTELLA, Eduardo et. al. O período moderno. Rio de Janeiro: Museu Nacional de Belas Artes, 1981. p.21-29.

PRADO, Paulo. Poesia Pau-Brasil. In: ANDRADE, Oswald. Pau-Brasil. 7. ed. São Paulo: Globo, 2001. p. 57-60.

ROCHA, João Cezar de Castro. Machado de Assis: por uma poética da emulação. Rio de Janeiro: Civilização Brasileira, 2013. 
SANTIAGO, Silviano. A permanência do discurso da tradição no modernismo. In: SANTIAGO, Silviano. Nas malhas da letra. Rio de Janeiro: Rocco, 2002. p.108-144.

SOUZA, Eneida Maria de. A pedra mágica do discurso. 2. ed. Belo Horizonte: EdUFMG, 1999.

SÜSSEKIND, Flora. Cenas de fundação. In: FABRIS, Annateresa (org.). Modernidade e modernismo no Brasil. Campinas: Mercado de Letras, 1994. p.67-87.

TELES, Gilberto Mendonça. Vanguarda europeia e modernismo brasileiro. 11. ed. Petrópolis: Vozes, 1992. 